\title{
Evidence for (E)-pityol as an aggregation pheromone of Pityophthorus pubescens (Coleoptera: Curculionidae: Scolytinae)
}

\author{
Sergio López, Carmen Quero, Juan Carlos Iturrondobeitia, Ángel Guerrero, \\ Arturo Goldarazena
}

\begin{abstract}
We present evidence favoring the use of $(E)$-pityol as an aggregation pheromone in Pityophthorus pubescens (Marsham). (E)-Pityol was detected in effluvia of male and female $P$. pubescens, and antennae of both sexes responded to $(E)-(+)$-pityol in electroantennogram assays. In two-choice olfactometer tests, males significantly preferred $(E)-(+)$-pityol and $(E)-( \pm)$-pityol to blank controls at doses of 1,10 , and $100 \mathrm{ng}$, whereas females only showed a preference for $(E)$-pityol at the $1 \mathrm{ng}$ dose.
\end{abstract}

\begin{abstract}
Résumé - Dans ce travail, nous présentons la preuve de l'utilisation de $(E)$-pityol comme une phéromone d'agrégation par Pityophthorus pubescens (Marsham). (E)-Pityol a été détecté dans les volatiles des mâles et des femelles de $P$. pubescens et les antennes des deux sexes ont répondu au $(E)-(+)$-pityol lors des essais électrophysiologiques. Dans un olfactomètre à deux choix, les mâles ont montré une préférence significative pour $(E)-(+)$ - pityol et $(E)-( \pm)$-pityol aux doses de 1,10 , et $100 \mathrm{ng}$ par rapport au contrôle, alors que les femelles seulement ont montré une préférence pour $(E)$-pityol à la dose de $1 \mathrm{ng}$.
\end{abstract}

\section{Introduction}

Most species of twig beetles, Pityophthorus Eichhoff (Coleoptera: Curculionidae: Scolytinae), are considered polygamous (Bright 1981; Wood 1982), but there is evidence of monogamy in a few species (Pfeffer 1976; Bright 1981; Dallara et al. 2000). In polygamous species, a male selects the host, starts constructing an egg gallery with a nuptial chamber, and attracts females, which extend the egg gallery (Bright 1981; Kirkendall 1983).

Little is known about pheromone-based aggregation in the genus Pityophthorus. Vité (1965); however, Chararas (1966, 1975) observed that males of $P$. confertus Swaine, $P$. annectans LeConte, and $P$. pityographus
(Ratzeburg) attract conspecific females. Francke et al. (1987) identified (2R,5S)-2-(1-hydroxy-1methylethyl)-5-methyltetrahydrofuran $(E-(+)-$ pityol) and cis-1-(2-hydroxyethyl)-1-methyl-2-(1methylethenyl) cyclobutane $(( \pm)$-grandisol) from males of $P$. pityographus, and showed that both compounds were active in the field. $(E)-(+)$ Pityol was also found in males of $P$. carmeli Swaine and females of $P$. nitidulus Mannerheim and P. setosus (Blackman) (Dallara et al. 2000), and has been reported as the female-produced sex pheromone of the cone beetles Conophthorus resinosae Hopkins, C. coniperda (Schwarz), and C. ponderosae Hopkins (Coleoptera: Curculionidae: Scolytinae) (Birgersson et al. 1995; Pierce et al. 1995;

Received 17 February 2011. Accepted 1 May 2011.

S. López, A. Goldarazena, ${ }^{1}$ Department of Plant Production and Protection, Neiker-Tecnalia (Basque Institute of Agricultural Research and Development), Arkaute, 46. E-01080 Vitoria, Spain

C. Quero, Á. Guerrero, Department of Biological Chemistry and Molecular Modelling, Institut de Quimica Avançada de Catalunya, Consejo Superior de Investigaciones Científicas, Jordi Girona 18-26. E-08034, Barcelona, Spain

JC. Iturrondobeitia, Department of Zoology and Animal Cell Biology, University of the Basque Country, Sarriena s/n. E-48940, Leioa, Spain

${ }^{1}$ Corresponding author (e-mail: agoldarazena@neiker.net).

doi: 4039/n11-022 
Miller et al. 2000). In addition to pityol, the spiroacetal (5S,7S)-(-)-7-methyl-1,6-dioxaspiro[4.5]decane (conophthorin) has been identified as a semiochemical in species of Pityophthorus. Conopthorin is a component of the aggregation pheromone emitted by males of $P$. carmeli (Dallara et al. 2000) and is a male-produced repellent in some other scolytines (Kohnle et al. 1992; Birgersson et al. 1995; Pierce et al. 1995; de Groot and DeBarr 2000). (E)-(-)-Conophthorin, by itself, is not attractive to Pityophthorus species, and significantly reduces catches of $P$. setosus (predominantly males) to $(E)$-pityol (Dallara et al. 2000), suggesting that it acts as a synomone to reduce intraspecific competition between $P$. setosus, $P$. nitidulus, and $P$. carmeli, three species that cohabit in Pinus radiata $\mathrm{D}$. Don (Pinaceae) stands in central coastal California (Dallara et al. 2000).

Pityophthorus pubescens (Marsham) is the only Pityophthorus species known from $P$. radiata stands in the Basque Country (northern Spain) (López et al. 2007). It is associated with Fusarium circinatum (Niremberg and O’Donnell) (Hypocreales: Nectriaceae), the pathogen causing pitch canker disease (Romón et al. 2007). Pityophthorus setosus and $P$. carmeli have been associated with pitch canker-infected Monterey pines in California (Storer et al. 2004; Sakamoto et al. 2007). Our objectives were to identify the aggregation pheromone of $P$. pubescens and evaluate its biological activity in electroantennographic (EAG) and behavioral tests in the laboratory.

\section{Materials and methods}

\section{Beetles}

Specimens of $P$. pubescens were collected from infested branches of $P$. radiata from a stand located at Gorosika $\left(43^{\circ} 15^{\prime} \mathrm{N}\right.$, $02^{\circ} 42^{\prime} \mathrm{W}$ ), Basque Country. Infested branches were maintained in an incubator at $25^{\circ} \mathrm{C}$ and 65\% RH under a 10L:14D photoperiod, and beetles were collected by dissecting the branches with a microscalpel under a binocular microscope.

\section{Chemicals}

Racemic (E)-pityol (93.4\% chemical purity) was purchased from Contech Inc. (Delta British Columbia, Canada) and $(E)-(+)-$ pityol $(99 \%)$ (Mori and Puapoomchareon 1987) was provided by Prof. W. Francke (Institute of Organic Chemistry, University of Hamburg, Hamburg, Germany).

\section{Collection of volatiles}

Volatiles of $P$. pubescens were adsorbed on a Porapak Q column (50/80 mesh, Supelco, Bellefonte, Pennsylvania) using 200 beetles of each sex caged in a glass flask and exposed to a stream of charcoal-filtered air at a flow rate of $1 \mathrm{~L} / \mathrm{min}$ for $40 \mathrm{~h}$. Three independent sets of this system containing males, females, or no beetles (control) were operated simultaneously and two volatile collections and blanks (control) were made for each sex. Each column was extracted with $300 \mu \mathrm{L}$ of dichloromethane and the extract was stored at $-40{ }^{\circ} \mathrm{C}$ until used.

Additional volatile collections were obtained using a polydimethylsiloxane fiber $(100 \mu \mathrm{m})$ for solid-phase microextraction (SPME) (Supelco) (Belardi and Pawliszyn 1989; Matich et al. 1996). Two hundred individuals of each sex were placed in separate $40 \mathrm{~mL}$ vials $(29 \mathrm{~mm} \times 81 \mathrm{~mm})$ with a SPME fiber for $36 \mathrm{~h}$ under laboratory conditions (mean temperature $\left.23{ }^{\circ} \mathrm{C}, 65 \% \mathrm{RH}, 14 \mathrm{~L}: 10 \mathrm{D}\right)$. The fiber had been conditioned prior to use by inserting it into the injection port of a gas chromatograph (GC) for $15 \mathrm{~min}$. Two replicates were done for each sex, using 200 different beetles each time.

Volatiles from both collection methods were analyzed on a Thermo Finnigan Trace 2000 GC system coupled to a Trace MS quadrupole mass spectrometer (ThermoFisher Scientific, Madrid, Spain) using helium (1 $\mathrm{mL} / \mathrm{min})$ as the carrier gas. The samples were introduced in splitless mode at $250{ }^{\circ} \mathrm{C}$. The column used for analysis was a $30 \mathrm{~m} \times 0.25 \mathrm{~mm}$ i.d. $\times 0.25 \mu \mathrm{m}$ HP-5MS fused silica capillary (Agilent Technologies, Madrid, Spain). The following chromatographic conditions were used: injection at $60{ }^{\circ} \mathrm{C}$ for $5 \mathrm{~min}$, increasing by $5^{\circ} \mathrm{C} / \mathrm{min}$ to $280^{\circ} \mathrm{C}$, and then maintained at this temperature for $10 \mathrm{~min}$. Mass spectra were obtained 
under electron impact ionization mode at $70 \mathrm{eV}$ in the $40-400 \mathrm{~m} / \mathrm{z}$ range.

\section{EAG assays}

The EAG instrument was obtained from Syntech (Kirchzarten, Germany). EAG recordings were performed using $\mathrm{Ag}-\mathrm{AgCl}$ glass microcapillaries filled with Ringer solution. Each beetle was fixed upside down on a piece of double-sided sticky tape, and the head was excised using a microscalpel. The recording electrode was connected to the tip of an antenna and the reference electrode was inserted into the occipital foramen using MP15 micromanipulators (Syntech). Humidified pure air $(1000 \mathrm{~mL} / \mathrm{min})$ was continuously directed over the antenna. The signals were amplified $(100 \times)$ and filtered (DC to $1 \mathrm{kHz})$ with a IDAC-2 interface (Syntech), digitized on a PC, and analyzed with the EAG Pro program. The EAG system was set up in a Faraday cage $(70 \mathrm{~cm} \times 65 \mathrm{~cm} \times 60 \mathrm{~cm})$ to preclude external electric signals. A log dilution series of $(E)-(+)$-pityol in hexane was prepared at doses of $0.1,1,10$, and $100 \mathrm{ng} / \mu \mathrm{L}$. Odor stimuli consisted of applying $10 \mu \mathrm{L}$ of a given concentration to a filter-paper strip $(2.5 \mathrm{~cm}$ i.d.) that was then placed inside a Pasteur pipette. After evaporation of the solvent, puffs of $400 \mathrm{~ms}$ duration through the Pasteur pipette placed $2 \mathrm{~cm}$ from the antennal setup were pulsed with a stimulus controller, CS-01 (Syntech). The recovery time for the antenna between two consecutive stimuli was established at $1-1.5 \mathrm{~min}$. Eight individuals of each sex were used with each dose of $(E)-(+)$ pityol and only one antenna was used per beetle. Three puffs of each dose of $(E)-(+)-$ pityol were applied and the mean amplitude of depolarization was subtracted from that in response to puffs of the hexane control, before and after each stimulus. Stimuli were delivered in order of increasing dose.

\section{Behavioral response}

The behavioral responses of male and female $P$. pubescens to three different doses of $(E)-(+)$-pityol and $(E)-( \pm)$-pityol were evaluated using a Y-tube olfactometer de- signed for small beetles ( $5 \mathrm{~mm}$ i.d., main arm $5 \mathrm{~cm}$ long, short arms $4 \mathrm{~cm}$ long, $90^{\circ}$ angle between short arms). Each short arm of the olfactometer was connected to a glass chamber containing the odor source. One of the arms contained $10 \mu \mathrm{L}$ of hexane on a circle of filter paper $(2.5 \mathrm{~cm}$ diameter) as a control, while the other contained a piece of filter paper of similar size treated with the test chemical. Different doses of the semiochemical were obtained from $10 \mu \mathrm{L}$ of decadic dilutions in hexane containing $0.1,1$, and $10 \mathrm{ng} / \mu \mathrm{L}$. Filter papers were replaced in each arm for every second beetle. Incoming air was filtered through activated charcoal and the airflow was maintained at $820 \mathrm{~mL} / \mathrm{min}$.

All tests were conducted at $23 \pm 1{ }^{\circ} \mathrm{C}$, $50 \pm 9 \% \mathrm{RH}$, and beetles were acclimatized to conditions for $15 \mathrm{~min}$ before the assays. Each beetle was observed for a maximum of $5 \mathrm{~min}$ and was used only once. A response was considered positive when the beetle walked at least $3 \mathrm{~cm}$ into one of the arms. The arms were reversed after five beetles were tested, to avoid directional bias. After 10 individuals were tested, the olfactometer was cleaned first with soap and water and then with absolute ethanol, and left to dry until the solvent had completely evaporated. In total, 35-40 different beetles were used for each sex and dose.

\section{Statistical analysis}

Data on the EAG response to $(E)-(+)$-pityol concentrations and sex were subjected to two-way ANOVA, followed by Tukey's posthoc tests at a significance level of $\alpha=0.05$. In olfactometer trials, the null hypothesis that $P$. pubescens showed no preference for either olfactometer arm (a response equal to 50:50) was analyzed by a $\chi^{2}$ test.

\section{Results}

\section{Volatile collections}

GC-mass spectrometry analyses of volatile collections trapped on Porapak Q or by SPME revealed the presence of $(E)$-pityol in both sexes of $P$. pubescens by comparing its retention time and mass spectra with those of 
Fig. 1. Amplified region of the gas chromatogram of a standard sample of $(E)-(+)$-pityol (A) and a dichloromethane extract of headspace volatiles of male (B) and female (C) Pityophthorus pubescens trapped on Porapak Q. The numeral above each peak represents the retention time (minutes). See Materials and methods for gas chromatographic conditions.

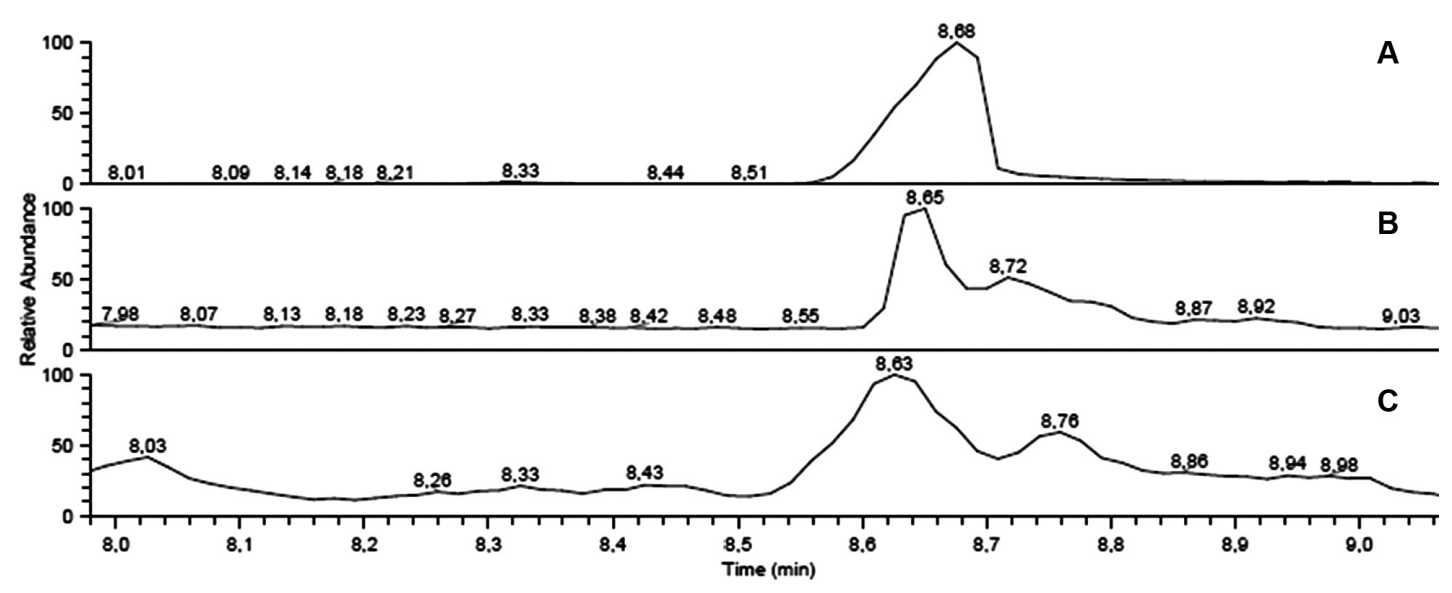

an authentic standard (Francke et al. 1987) (Figs. 1, 2). All spectra exhibited a base peak at $\mathrm{m} / \mathrm{z} 59$, suggesting a tertiary alcohol, and prominent peaks at 85,102 , and $129 \mathrm{~m} / \mathrm{z}$. The intense fragment ion of $\mathrm{m} / \mathrm{z} 85$ in the mass spectrum reflects the presence of a tetrahydropyran or methyl-substituted tetrahydrofuran ring as a partial structure. The amount of $(E)$ $(+)$-pityol emitted was not compared between the sexes. As expected, no traces of $(E)$-pityol were found when the controls of both sexes were analyzed.

\section{EAG response of $\boldsymbol{P}$. pubescens to $(\boldsymbol{E})-(+)$-pityol}

$(E)-(+)$-Pityol elicited electrophysiological responses from the antennae of both sexes (0.1-0.2 mV, on average) (Fig. 3). The mean amplitude of depolarization was not significantly affected by $\operatorname{sex}\left(F_{1,56}=1.050, P=\right.$ $0.310)$ or dose $\left(F_{3,56}=0.700, P=0.476\right)$, but the interaction between sex and dose was nearly significant $\left(F_{3,56}=2.356, P=0.083\right)$. Therefore, we compared responses among all eight sex-dose combinations using Tukey's post-hoc test. From this analysis it was clear that male antennae responded most strongly to the lowest dose of $(E)-(+)$-pityol $(1 \mathrm{ng})$, whereas female antennae responded most strongly to the highest dose (1000 ng) (Fig. 3).

\section{Behavioral response}

Male $P$. pubescens significantly preferred the olfactometer arm containing either racemic $(E)$-pityol or $(E)-(+)$-pityol at all three doses tested (Fig. 4A). The lowest doses (1 ng for the racemic material and $1-10 \mathrm{ng}$ for the chiral material) proved to be the most attractive. However, females were attracted only to the lowest dose (1 ng) of racemic (E)-pityol and (E)-(+)-pityol (Fig. 4B). Moreover, they significantly avoided racemic $(E)$-pityol at doses of 10 and $100 \mathrm{ng}$.

\section{Discussion}

We isolated and identified (E)-pityol in volatiles of male and female $P$. pubescens, and demonstrated an electrophysiological response to $(E)-(+)$-pityol in the antennae of both sexes, as well as a dose-dependant behavioral response of both sexes to racemic $(E)$-pityol and $(E)-(+)$-pityol in olfactometer bioassays. These results suggest that $(E)-(+)$-pityol may be a key compound in the chemical ecology of P. pubescens. Prior to our study, $(E)-(+)$-pityol had been detected in several Pityophthorus species but always in one sex only, e.g., males of $P$. carmeli and $P$. pityographus and females of $P$. setosus and $P$. nitidulus. In field tests, males of $P$. setosus, a monogamous species, 
Fig. 2. Mass spectra of a standard sample of $(E)-(+)$-pityol (A), male Pityophthorus pubescens (B), and

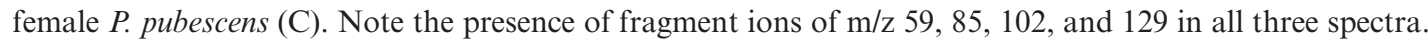

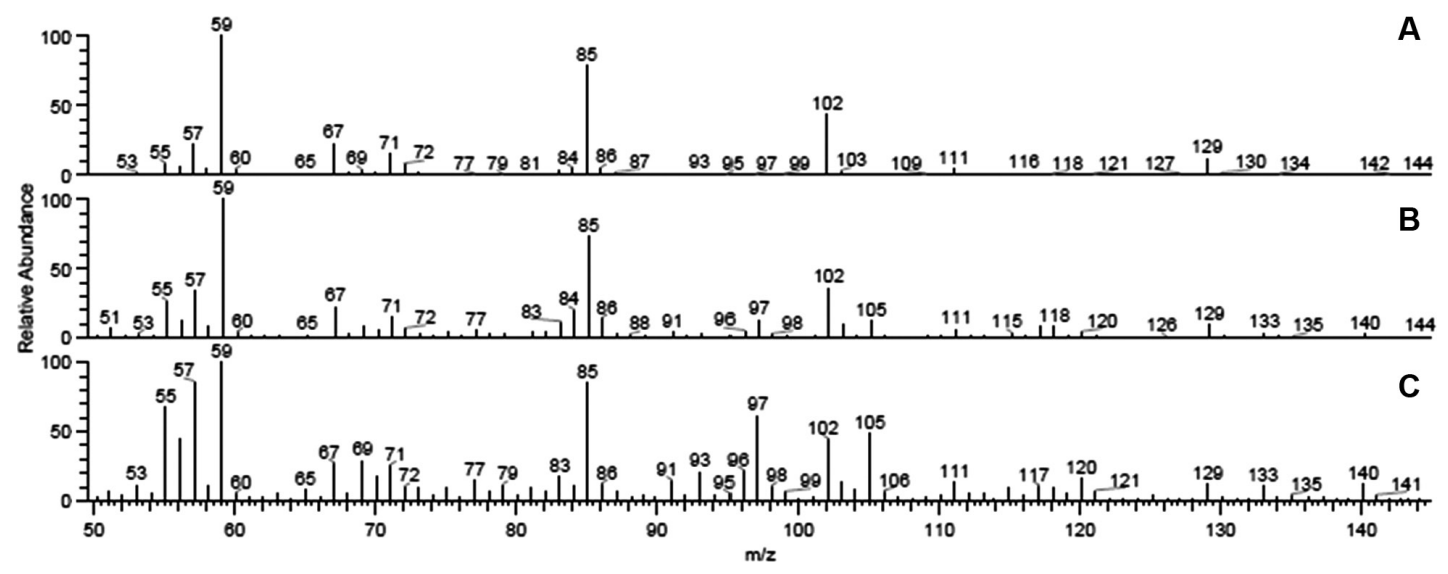

Fig. 3. Absolute EAG responses (mean $\pm \mathrm{SE}$ ) of Pityophthorus pubescens males (dark shading) and females (light shading) to serial dilutions containing $1,10,100$, and $1000 \mathrm{ng}$ of $(E)-(+)$-pityol. A different letter above the bar indicates a significant difference (two-way ANOVA followed by Tukey's multiple range test $(P \leq 0.05), n=8)$.

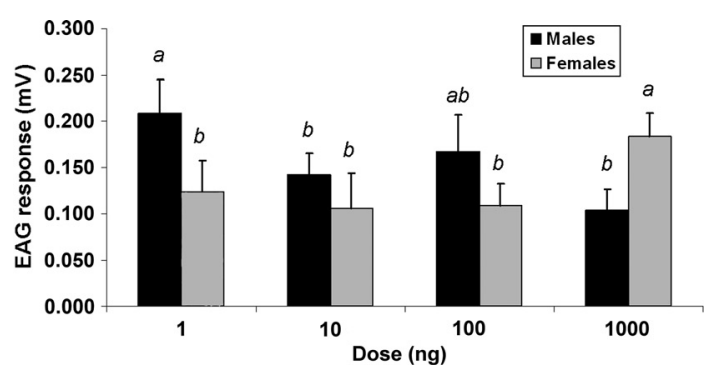

responded strongly to $(E)-(+)$-pityol alone (Dallara et al. 2000), whereas P. pityographus, a polygamous species, was attracted by the combination of grandisol and $(E)-(+)$-pityol (Francke et al. 1987). Another polygamous species, $P$. carmeli, was attracted only by the combination of $(E)-(+)$-pityol and $(E)-(-)$ conophthorin (Dallara et al. 2000). Similarly, in species of Conophthorus Hopkins (a genus considered to be phylogenetically closely related to Pityophthorus) (Cognato et al. 2005), $(E)-(+)$-pityol is known to be the major compound of its sex pheromone and has been found only in females (Birgersson et al. 1995; Pierce et al. 1995; Miller et al. 2000).
During dissection of naturally infested branches to collect beetles, we observed that all galleries contained a single mating pair of $P$. pubescens, and had a longitudinal pattern without a nuptial chamber, which is consistent with monogamy. However, it would be necessary to carry out a more extensive study of the gallery patterns from more naturally collected branches to allow us to draw accurate conclusions.

Although we found (E)-pityol in both sexes, the enantiomeric composition of the natural material has not been elucidated. Chirality plays an important role in determining pheromone specificity. In $60 \%$ of species and sex/ aggregation systems studied to date, only a single enantiomer is bioactive, and its opposite enantiomer does not inhibit the response to the active stereoisomer in racemic blends (Mori 2007), but in some species the antipode can significantly reduce the attractive response to the active enantiomer (Birch et al. 1980; Leal 1996; Lacey et al. 2004). Owing to the lack of the $(-)$-enantiomer in our behavioral assays, its biological activity cannot be inferred. However, the racemic mixture was attractive, as was the pure $(+)$-enantiomer, to male $P$. pubescens when tested in the olfactometer, suggesting that $(E)-(-)$-pityol could be behaviorally inactive for males. This is consistent with the lack of response of other Pityophthorus species to (E)-(-)-pityol (Francke et al. 1987; Dallara et al. 2000; 
Fig. 4. Responses of Pityophthorus pubescens males and females to different doses of $(E)-(+)$-pityol and racemic $(E)$-pityol in Y-tube olfactometer trials $\left({ }^{*}, P<0.05{ }^{* *}, P<0.01\right)$. Numbers in parentheses denote the number of beetles that responded.

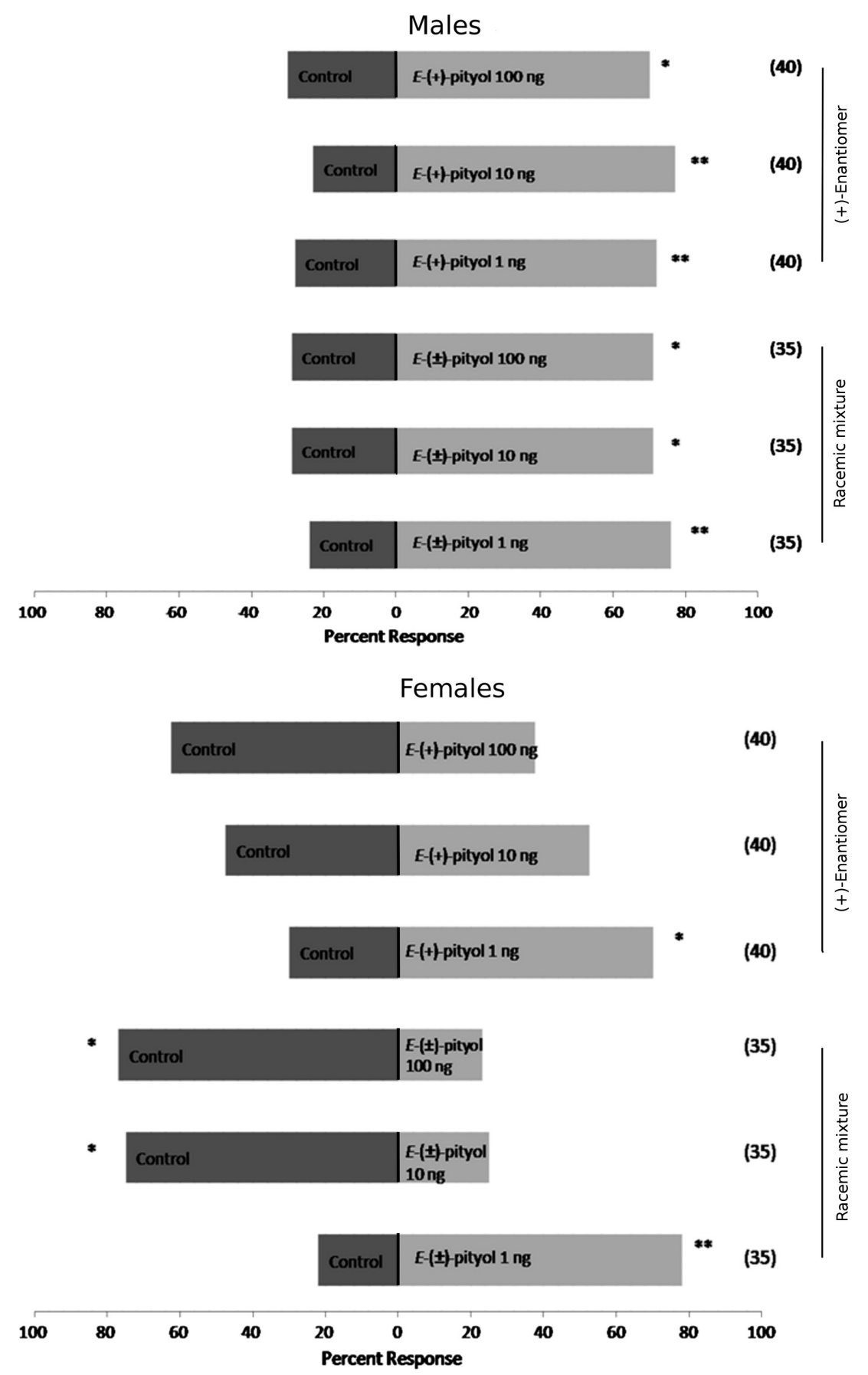

W. Francke, personal communication). In contrast, females were only attracted to the lowest dose in both cases, showing a signifi- cant preference for the blank arm when the racemic mixture was tested (and it is evident that increasing the $(E)-(+)$-pityol dose leads 
to an apparent and progressive decrease of the positive response, although this is not statistically significant). In light of our results we cannot assert that this behavior is caused by the presence of $(E)-(-)$-pityol; further studies would be needed to determine the biological influence of each enantiomer on $P$. pubescens.

We report the first electroantennographic assays performed on a species of Pityophthorus and show that the antennae of both sexes of $P$. pubescens respond to $(E)-(+)$-pityol. Interestingly, whereas female antennae showed the greatest response to the highest dose, the reverse was true for male antennae, i.e., they showed the greatest response to the lowest dose.

In summary, for the first time we detected the presence of $(E)$-pityol as a possible aggregation pheromone in male and female volatiles of $P$. pubescens, and demonstrated the biological activity of the $(+)$-enantiomer and the racemate in electrophysiological and behavioral studies. Studies should be carried out to confirm the attraction of both sexes of $P$. pubescens in the field for these chemicals.

\section{Acknowledgements}

Thanks are extended to the Department of Education, Universities and Research of the Basque Country for awarding a Ph.D. fellowship to S.L., and to the Department of Agriculture and Fisheries of the Basque Country and the Ministerio de Ciencia e Innovación (project AGL2009-13452-C02-01) for financial support. Thanks are also extended to Prof. Rafael Jordana (Department of Zoology and Ecology, University of Navarra, Spain) and Prof. Wittko Francke (Institute of Organic Chemistry, University of Hamburg, Hamburg, Germany) for comments and suggestions on earlier versions of the manuscript, and to Pedro Romón for his assistance and suggestions for the experimental design. We are indebted to members of Neiker-Tecnalia, Biscay Government, and of the Chemical Ecology Unit, Institut de Quimica Avançada de Catalunya, for technical assistance. Prof. Francke kindly provided pure $(E)-(+)$-pityol.

\section{References}

Belardi, R.P., and Pawliszyn, J.B. 1989. The application of chemically modified fused silica fibers in the extraction of organics from water matrix samples and their rapid transfer to capillary columns. Water Pollution Research Journal of Canada, 24: 179-191.

Birch, M.C., Light, D.M., Wood, D.L., Browne, L.E., Silverstein, R.M., Bergot, B.J., et al. 1980. Pheromonal attraction and allomonal interruption of Ips pini in California by the two enantiomers of ipsdienol. Journal of Chemical Ecology, 6: 703-717. doi: 10.1007/BF00987680.

Birgersson, G., DeBarr, G.L., de Groot, P., Dalusky, M.J., Pierce, H.D., Jr., Borden, J.H., et al. 1995. Pheromones in white pine cone beetle, Conophthorus coniperda (Schwarz) (Coleoptera: Scolytidae). Journal of Chemical Ecology, 21: 143-167.

Bright, D.E. 1981. Taxonomic monograph of the genus Pityophthorus Eichhoff in North and Central America (Coleoptera: Scolytidae). Memoirs of the Entomological Society of Canada No. 118.

Chararas, C. 1966. Recherches sur l'attractivité chez les Scolytidae: étude sur l'attractivité sexuelle chez Carphoborus minimus Fabr. Coléoptère Scolytidae typiquement polygame. Comptes Rendus Hebdomadaires des Séances de 1'Academie des Sciences Serie D Paris, 262: 2492-2495.

Chararas, C. 1975. Spécifité de la réponse des Scolytidae monogames et polygames a l'attraction exercée par les résidus de la digestión (déjections). Comptes Rendus Hebdomadaires des Séances de l' Academie des Sciences Serie D Paris, 280: 2567-2570.

Cognato, A.I., Gillette, N.E., Bolaños, R.C., and Sperling, F.A.H. 2005. Mitochondrial phylogeny of pine cone beetles (Scolytinae, Conophthorus) and their affiliation with geographic area and host. Molecular Phylogenetics and Evolution, 36: 494-508.

Dallara, P.L., Seybold, S.J., Meyer, H., Tolasch, T., Francke, W., and Wood, D.L. 2000. Semiochemicals from three species of Pityophthorus (Coleoptera: Scolytidae): identification and field response. The Canadian Entomologist, 132: 889-906.

de Groot, P., and DeBarr, G.L. 2000. Response of cone and twig beetles (Coleoptera: Scolytidae) and a predator (Coleoptera: Cleridae) to pityol, conophthorin, and verbenone. The Canadian Entomologist, 132: 843-851.

Francke, W., Pan, M.L., König, W.A., Mori, K., Puapoomchareon, P., Heuer, H. and Vité, J.P. 1987. Identification of 'pityol' and 'grandisol' as pheromone components of the bark beetle, 
Pityophthorus pityographus. Naturwissenschaften, 74: 343-345. doi: 10.1007/BF00367933.

Kirkendall, L.R. 1983. The evolution of mating systems in bark and ambrosia beetles (Coleoptera: Scolytidae and Platypodidae). Zoological Journal of the Linnean Society, 77: 293-352. doi: 10.1111/j.1096-3642.1983.tb00858.x.

Kohnle, U., Densborn, S., Kölsch, P., Meyer, H., and Francke, W. 1992. E-7-Methyl-1,6-dioxaspiro[4.5]decane in the chemical communication of European Scolytidae and Nitidulidae (Coleoptera). Journal of Applied Entomology, 114: 187192. doi: 10.1111/j.1439-0418.1992.tb01113.x.

Lacey, E.S., Moreira, J.A., Millar, J.G., Ray, A.M., and Hanks, L.M. 2004. Male-produced aggregation pheromone of the cerambycid beetle Neoclytus mucronatus mucronatus. Journal of Chemical Ecology, 30: 1493-1507.

Leal, W.S. 1996. Chemical communication in scarab beetles: reciprocal behavioral agonistantagonist activities of chiral pheromones. Proceedings of the National Academy of Sciences of the United States of America, 93: 12112-12115.

López, S., Romón, P., Iturrondobeitia, J.C., and Goldarazena A. 2007. Conifer bark beetles of Basque Country: practical guide for identification and control. Basque Government Publication Service, Vitoria, The Basque Country, Spain. [In Spanish.]

Matich, A.J., Rowan, D.D., and Banks, N.H. 1996. Solid phase microextraction for quantitative headspace sampling of apple volatiles. Analytical Chemistry, 68: 4114-4118. doi: 10.1021/ac960 4548.

Miller, D.R., Pierce, H.D., Jr., de Groot, P., JeanWilliams, N., Bennett, R., and Borden, J.H. 2000. Sex pheromone of Conophthorus ponderosae (Coleoptera: Scolytidae) in a coastal stand of western white pine (Pinaceae). The Canadian Entomologist, 132: 243-245.

Mori, K. 2007. Significance of chirality in pheromone science. Bioorganic and Medicinal Chemistry, 15: 7505-7523. doi: 10.1016/j.bmc. 2007.08.040.
Mori, K., and Puapoomchareon, P. 1987. Conversion of the enantiomers of sulcatol (5-methyl-5hepten-2-ol) to the enantiomers of pityol (trans2-(1-hydroxy-1-methylethyl)-5-methyltetrahydrofuran), a male specific attractant of the bark beetle Pityophthorus pityographus. Liebigs Annalen der Chemie, 3: 271-272. doi: 10.1002/ jlac. 198719870321.

Pfeffer, A. 1976. Revision der paläarktischen Arten der Gattung Pityophthorus Eichhoff (Coleoptera: Scolytidae). Acta Entomologica Bohemoslovaca, 73: $324-342$.

Pierce, H.D., de Groot, P., Borden, J.H., Ramaswamy, S., and Oehlschlager, A.C. 1995. Pheromones in red pine cone beetle, Conophthorus resinosae Hopkins, and its synonym, C. banksianae McPherson (Coleoptera: Scolytidae). Journal of Chemical Ecology, 21: 169-185. doi: 10.1007/BF02036649.

Romón, P., Iturrondobeitia, J.C., Gibson, K., Lindgren, B.S., and Goldarazena, A. 2007. Quantitative association of bark beetles with pitch canker fungus and effect of verbenone on their semiochemical communication in Monterey pine forests in northern Spain. Environmental Entomology, 36: 743-750.

Sakamoto, J.M., Gordon, T.R., Storer, A.J., and Wood, D.L. 2007. The role of Pityophthorus spp. as vectors of pitch canker affecting Monterey pines (Pinus radiata). The Canadian Entomologist, 139: 864-871.doi: 10.4039/n07-022.

Storer, A.J., Wood, D.L., and Gordon, T.R. 2004. Twig beetles, Pityophthorus spp. (Coleoptera: Scolytidae), as vectors of the pitch canker pathogen in California. The Canadian Entomologist, 136: 685-693. doi: 10.4039/n03-118.

Vité, J.P. 1965. Die Wirkung pflanzen- und insekteneigener Lockstoffe auf Pityophthorus and Pityogenes (Coleoptera: Scolytidae). Naturwissenschaften, 52: 267.

Wood, S.L. 1982. The bark and ambrosia beetles of North and Central America, a taxonomic monograph. Great Basin Naturalist Memoirs, 6: $1-1359$ 